\title{
Thermal requirements, growth and yield of pigeonpea [Cajanus cajan (L.) Millsp.] genotypes under different agroclimatic zones of Punjab
}

\author{
Guriqbal Singh $^{1 *}$, Harpreet Kaur Virk ${ }^{1}$, Sudeep Singh ${ }^{2}$, Kulvir Singh ${ }^{3}$, Satpal Singh ${ }^{4}$ and K.K. Gill ${ }^{5}$ \\ ${ }^{1}$ Department of Plant Breeding and Genetics, Punjab Agricultural University, Ludhiana -141004 (Punjab), INDIA \\ ${ }^{2}$ Punjab Agricultural University, Regional Research Station, Bathinda (Punjab), INDIA \\ ${ }^{3}$ Punjab Agricultural University, Regional Research Station, Faridkot (Punjab), INDIA \\ ${ }^{4}$ Punjab Agricultural University, Regional Research Station, Gurdaspur (Punjab), INDIA \\ ${ }^{5}$ School of Climate Change and Agricultural Meteorology, Punjab Agricultural University (PAU), Ludhiana - \\ 141004 (Punjab), INDIA \\ *Corresponding author. E-mail: singhguriqbal@pau.edu
}

Received: April 12, 2017; Revised received: June 11, 2017; Accepted: October 30, 2017

\begin{abstract}
A field experiment was carried out at four locations i.e. Ludhiana, Bathinda, Faridkot and Gurdaspur to study the influence of diverse environments on symbiotic traits, thermal requirements, growth in terms of plant height $(\mathrm{cm})$ and yield (kg/ha) of pigeonpea [cajanus cajan (L.) Millsp.] genotypes under different agroclimatic zones of Punjab. Results indicated that crop sown on 15 May recorded the higher grain yield than later sowing dates of 1 June and 15 June at all the locations; 15 May sowing provided 23.3, 22.1 and 46.7\% higher grain yield over 1 May, 1 June and 15 June sowing, respectively. Early sown crop acquired higher agro-climatic indices than delayed sowings. The crop sown on 15 May provided the maximum gross returns, net returns and B:C ratio as evident from the additional income of Rs 13599, 13040 and 22865 Rs/ha over 1 May, 1 June and 15 June sowing, respectively. Among the genotypes, AL 201 at Ludhiana and Gurdaspur, AL 1578 at Bathinda and PAU 881 at Faridkot resulted in the highest grain yield and maximum returns. The genotype $A L 201$ took more days to $50 \%$ flowering and maturity at all the locations. It can be concluded that 15 May is the optimum sowing date and AL 201 and PAU 881 are the promising genotypes for providing high productivity of pigeonpea under different agroclimatic zones of Punjab.
\end{abstract}

Keywords: Genotype, Grain yield, Pigeonpea, Sowing date, Thermal requirements

\section{INTRODUCTION}

Pigeonpea [Cajanus cajan (L.) Millsp.] is an important legume crop widely cultivated in the world. In India, during 2014 pigeonpea was grown on 5.60 million ha with total production of 3.29 million tonnes and productivity of $587 \mathrm{~kg} / \mathrm{ha}$ (FAOSTAT 2017). Its grains are rich in high digestible protein $(21.7 \mathrm{~g} / 100 \mathrm{~g})$, low in fat $(1.49 \mathrm{~g} / 100 \mathrm{~g})$ with no cholesterol and high dietary fibres. Being a non-monetary input, sowing time significantly influences the growth and grain yield of pigeonpea (Wilson et al., 2012; Egbe et al., 2013; Singh et al., 2016). Delayed sowings beyond the optimum period result in low grain yields of pigeonpea (Kumar et al., 2008). Genotypes may vary in productivity (Egbe and Vange, 2008; Bhavi et al., 2013; Umesh et al., 2013; Singh et al., 2016) and the yield potential of the genotypes can be fully exploited through providing appropriate microclimate temperature between 18 and $29{ }^{\circ} \mathrm{C}$ at different growth and development phases.

All biological processes of crops respond to tempera- ture and all responses can be summarized in terms of three cardinal temperatures: a base or minimum, an optimum and a maximum temperature. The crop needs moist and warm weather. The temperature requirement during germination, active vegetative growth, flowering and pod setting and maturity ranges between 30-35 ${ }^{\circ} \mathrm{C}, 20-25^{\circ} \mathrm{C}, 15-18{ }^{\circ} \mathrm{C}$ and $35-40{ }^{\circ} \mathrm{C}$, respectively. However, the nature of the response to temperature between these cardinal points is important for calculating the phenology, adaptation and yield of a crop (Singh and Singh 2011). Air temperature based meteorological indices viz. growing degree days (GDD), heliothermal units (HTU) and photothermal units (PTU) are used to describe changes in phenology and growth parameters (Prakash et al., 2015). The progress in terms of growth is estimated by integrating a developmental rate, which is usually a function of temperature and photoperiod. Besides, heat use efficiency i.e. efficiency of utilization of heat in terms of dry matter production or grain yield is another important aspect which has practical utility. Efficiency of heat energy conversion for dry matter production depends on genetic factors, crop and the growing environment. Several phenological models have been prepared to predict 
the duration required to attain different phenophases by using growing degree-days (GDD), photothermal units (PTU) and other crop thermal units (Esfandiary et al., 2009). GDD and PTU are good estimators of growth stages in different crops like sorghum (Prakash et al., 2017) and wheat (Pandey et al., 2010) and finally to predict the yield in view of different climatic changes.

In Punjab, the recommended time of sowing of pigeonpea was first fortnight of June (PAU 2011). However, with the changing climate, the optimum time of sowing is also subjected to changes. Furthermore, when the crop is sown during first fortnight of June, mostly the crop maturity is delayed, causing delayed harvesting and consequently late sowing of succeeding wheat crop also leads to low productivity. About $375 \mathrm{~kg} / \mathrm{ha}$ wheat grain yield is reduced with a delay of one week in sowing (PAU 2011). In Northern India, only those genotypes of pigeonpea are required which may fit well in pigeonpea-wheat cropping system (Sekhon and Singh 2005). Based on different climatic conditions, Punjab state has been divided into six diverse agroclimatic zones and to draw conclusive inferences, experiments were conducted in 3 prime zones having pigeonpea acreage i.e. central plain zone (Ludhiana), submontane zone (Gurdaspur) and south-western plain arid zone (Faridkot and Bathinda). Keeping all these factors in mind, the present experiments were conducted at four places in three different agroclimatic zones of Punjab to study the influence of diverse environments on symbiotic traits, thermal requirements, growth and yield of pigeonpea genotypes.

\section{MATERIALS AND METHODS}

Field experiments were conducted during kharif (rainy season) 2011 at the research farm of the Punjab Agricultural University, Ludhiana $\left(30^{\circ} 54^{\prime} \mathrm{N}, 75^{\circ} 48^{\prime} \mathrm{E}\right.$, altitude $247 \mathrm{~m}$ ) and its Regional Research Stations at Gurdaspur $\left(31^{\circ} 94^{\prime} \mathrm{N}\right.$ and $75^{\circ} 24^{\prime} \mathrm{E}$ altitude $\left.241 \mathrm{~m}\right)$, Bathinda $\left(30^{\circ} 21 \mathrm{~N}\right.$ and $74^{\circ} 94^{\prime} \mathrm{E}$ altitude $\left.210 \mathrm{~m}\right)$ and Faridkot $\left(30^{\circ} 40^{\prime} \mathrm{N}\right.$ and $74^{\circ} 44^{\prime} \mathrm{E}$ altitude $\left.211 \mathrm{~m}\right)$. Meteorological data during the crop season were recorded from the Meteorological Observatories and weekly mean of maximum $\&$ minimum temperature, total rainfall and sunshine hours are presented in Fig. 1.

The experiment comprised of four dates of sowing (1 May, 15 May, 1 June and 15 June) in main plots and four genotypes (AL 15, AL 201, PAU 881 and AL 1578) in sub-plots at Ludhiana, Gurdaspur \& Bathinda whereas at Faridkot these genotypes were tested under three dates of sowing (15 May, 1 June and 15 June) . The experiment was laid out in split-plot design with four replications. Nutrients viz. $15 \mathrm{~kg} \mathrm{~N} / \mathrm{ha}$ and $40 \mathrm{~kg}$ $\mathrm{P}_{2} \mathrm{O}_{5} /$ ha were applied entirely as basal dose to the crop and the crop was sown in rows $50 \mathrm{~cm}$ apart using a seed rate of $15 \mathrm{~kg} / \mathrm{ha}$. Weeds were controlled by spraying pendimethalin (Stomp 30 EC) @ 0.45 a.i. kg/ha as pre-emergence by using 500 litres of water followed by hand weeding at six weeks after sowing. The crop was raised with the recommended package of practices (PAU 2011).

Days taken to $50 \%$ flowering and maturity were recorded for each genotype sown under different dates. The accumulated GDD for each phenophase were calculated by applying the following equation (Nuttonson 1955):

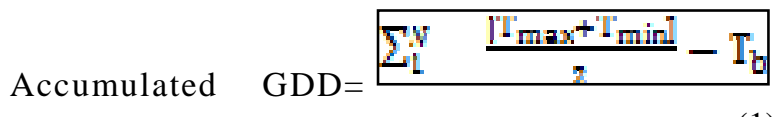

Where, $\mathrm{T}_{\max }$, daily maximum temperature $\left({ }^{\circ} \mathrm{C}\right), \mathrm{T}_{\min }$, daily minimum temperature $\left({ }^{\circ} \mathrm{C}\right)$,

$\mathrm{T}_{\mathrm{b}}$, base temperature of $10.0{ }^{\circ} \mathrm{C}$

$1=$ Start of phenophase or date of sowing, $\mathrm{N}=$ End of phenophase or date of physiological maturity

Photothermal units (PTU), the product of GDD and corresponding day length for that day were computed on daily basis as follows:

$\mathrm{PTU}=\mathrm{GDD} \times$ Day length

Where day length refers to maximum possible sunshine hours.

Heat use efficiency (HUE) was calculated as follows: Heat use efflclency (HUE) $=\frac{\text { Grain pield ha bay }}{\text { Arrumulated featunits (c day }}$

Growing degree days and photothermal units were accumulated from the date of sowing to $50 \%$ flowering and maturity to give accumulated indices. Heat use efficiency was calculated after harvesting of the crop. Data on plant height, branches/plant and pods/plant were recorded at harvest from five randomly selected plants from each plot excluding border rows. Biological yield (all above-ground plant parts) and grain yield were recorded on the whole plot basis and expressed in $\mathrm{kg} / \mathrm{ha}$. Grains/pod were recorded from average value of twenty pods per plot. The data on 100-grain weight were recorded after taking 100 randomly selected grains. Harvest index (\%) was calculated by dividing grain yield by biological yield and multiplied by 100 . Gross returns, net returns as well as Benefit: Cost $(\mathrm{B}: \mathrm{C})$ ratio was worked out by using prevailing prices of inputs and output. Data were subjected to analysis of variance (ANOVA) in a split-plot design as per the standard procedure (Cheema and Singh, 1991).

\section{RESULTS AND DISCUSSION}

Effect of date of sowing: Data clearly revealed that days to $50 \%$ flowering and maturity were reduced with delay in sowing (Table 1). The earliest sown crop took more number of days to $50 \%$ flowering and maturity at Ludhiana as well as Faridkot. The crop sown on 15 May also took slightly higher number of days to $50 \%$ flowering and maturity than later sowings of 1 or 15 June. Early sown crop during May also matured earlier 

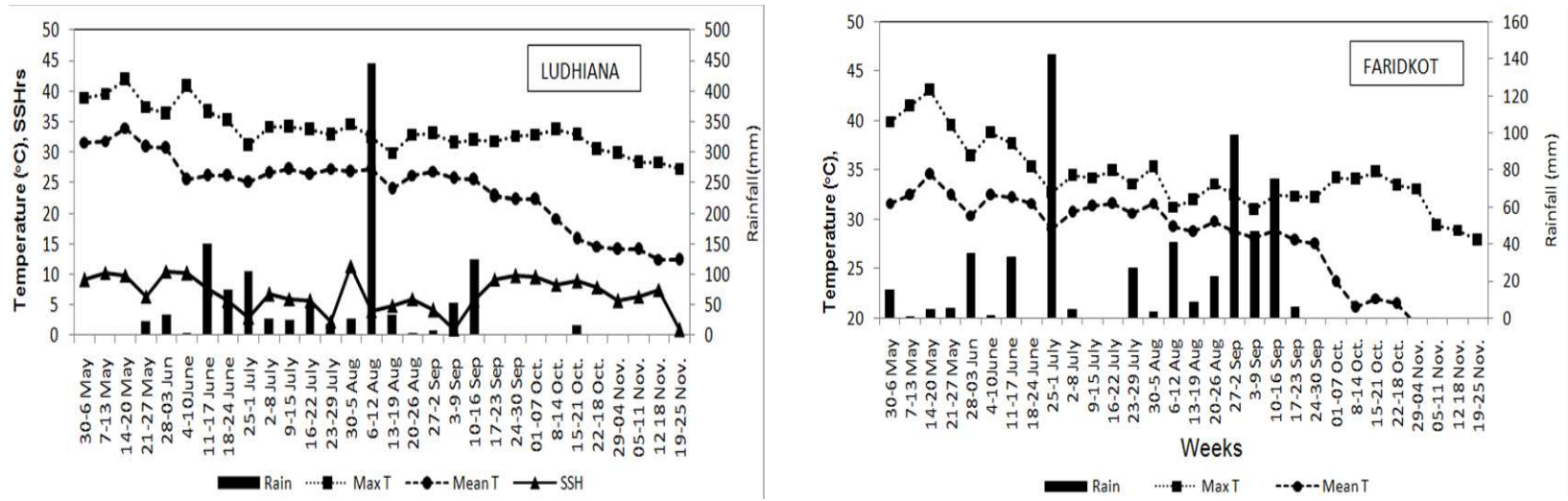

Fig. 1. Weekly mean weather conditions of maximum annd minimum temperature, rainfall and sunshine hours during crop season (2011) at Ludhiana and Faridkot.
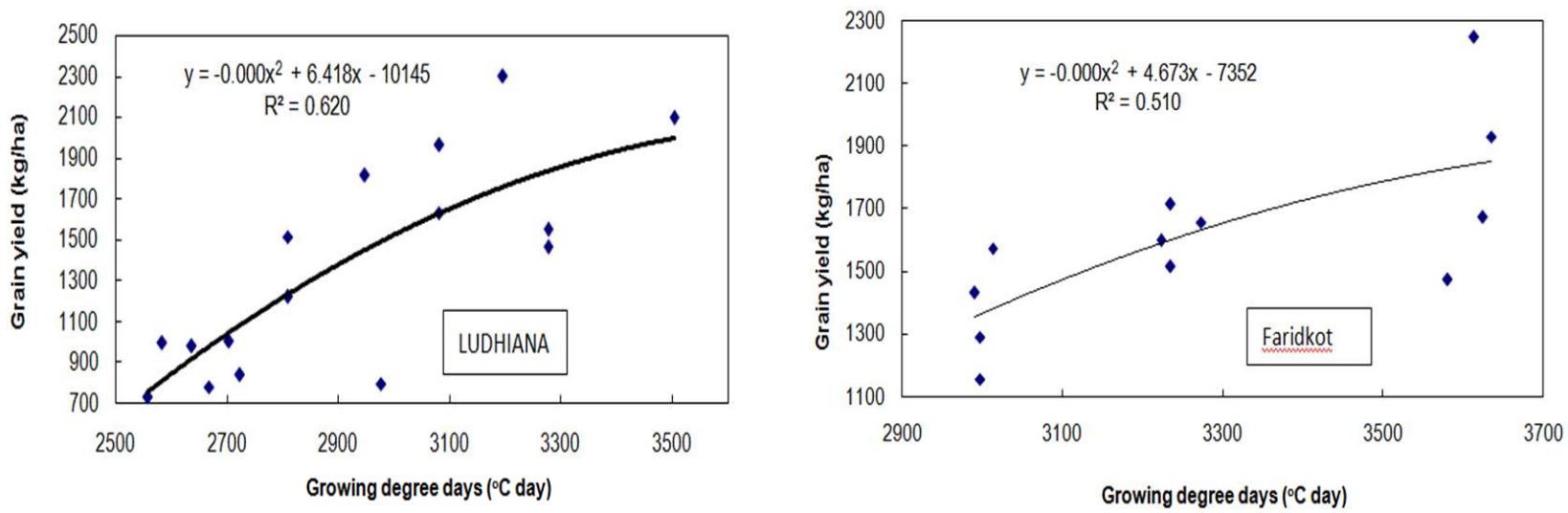

Fig.2. Relationship between accumulated growing degree days and grain yield in pigeonpea at Ludhiana and Faridkot.
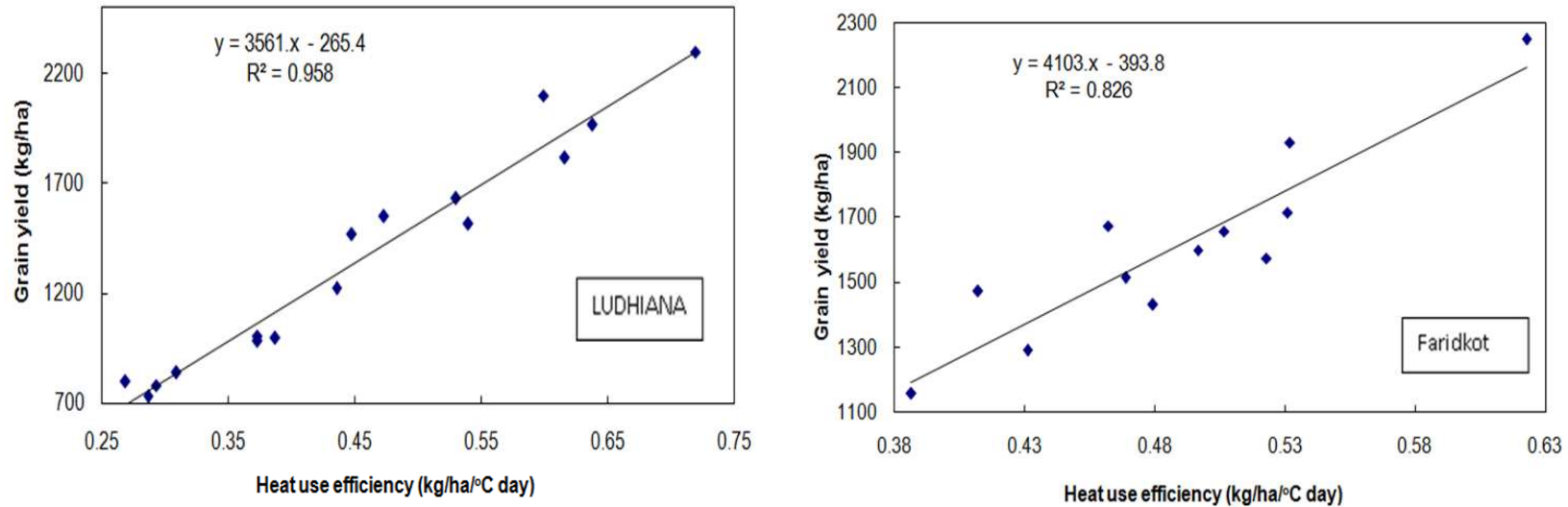

Fig.3. Relationship between heat use efficiency and grain yield in pigeonpea at Ludhiana and Faridkot.

than sowing in June, resulting in early harvest of the pigeonpea crop and thereby vacating the field earlier for timely sowing of the succeeding rabi season crop like wheat. The late sown crop took less number of days for maturity possibly due to completion of its various growth stages in a short period owing to decreasing temperatures.

The data on accumulated agroclimatic indices i.e. growing degree days, photothermal units and heat use efficiency computed for pigeonpea genotypes under varying dates of sowing from sowing to $50 \%$ flowering and physiological maturity at two different agroclimatic zones have been presented in Table 1. The accu- mulated growing degree days from sowing to maturity ranged from 2620-3259 ${ }^{\circ} \mathrm{C}$ days for Ludhiana and 3000-3613 ${ }^{\circ} \mathrm{C}$ days for Faridkot. It clearly elucidated that early sown crop accumulated higher heat units $\left(3259,3613^{\circ} \mathrm{C}\right.$ day) as compared to late sown crop $\left(2620,3000^{\circ} \mathrm{C}\right.$ day). Lower growing degree days for late sown crop were due to reduction in growing period. Khichar and Niwas (2007) also reported that the requirement of heat units decreased for different phenological stages with delay in sowing of wheat. The timely sown crop utilized heat more efficiently than late sown crop, resulting in highest grain yield under 15 May sowing and it showed a significant re- 
Table 1. Effect of date of sowing and genotypes on variousagroclimatic indices (GDD, PTU and heat use efficiency) of pigeonpea crop at Ludhiana and Faridkot.

\begin{tabular}{|c|c|c|c|c|c|c|c|c|c|}
\hline \multirow[b]{2}{*}{ Location } & \multirow[b]{2}{*}{ Treatment } & & \multicolumn{3}{|c|}{$50 \%$ flowering } & \multicolumn{4}{|c|}{ Physiological maturity } \\
\hline & & & DAS & $\begin{array}{c}\text { AGDD } \\
\left({ }^{\circ} \mathrm{C} \text { day }\right) \\
\end{array}$ & $\begin{array}{c}\text { APTU } \\
\left({ }^{\circ} \mathrm{C} \text { day }\right)\end{array}$ & DAS & $\begin{array}{l}\text { AGDD } \\
\left({ }^{\circ} \mathrm{C} \text { day }\right)\end{array}$ & $\begin{array}{c}\text { APTU } \\
\left(\left(^{\circ} \mathrm{C} \text { day }\right)\right.\end{array}$ & $\begin{array}{c}\text { HUE } \\
\left(\mathrm{kg} / \mathrm{ha} /{ }^{\circ} \mathrm{C} \text { day }\right)\end{array}$ \\
\hline \multirow[t]{8}{*}{ Ludhiana } & Date of & 1 May & 100 & 2088 & 28980 & 165 & 3259 & 43629 & 0.45 \\
\hline & sowing & 15 May & 99 & 2040 & 28260 & 155 & 3020 & 40265 & 0.55 \\
\hline & & 1 June & 97 & 1934 & 26493 & 150 & 2808 & 36893 & 0.47 \\
\hline & & 15 June & 94 & 1837 & 24768 & 146 & 2620 & 33893 & 0.35 \\
\hline & Genotype & AL 15 & 80 & 1644 & 22843 & 141 & 2731 & 36433 & 0.29 \\
\hline & & AL 201 & 106 & 2139 & 29231 & 166 & 3087 & 40467 & 0.58 \\
\hline & & PAU 881 & 102 & 2058 & 28213 & 155 & 2951 & 38962 & 0.51 \\
\hline & & AL 1578 & 102 & 2058 & 28213 & 154 & 2938 & 38818 & 0.45 \\
\hline \multirow[t]{7}{*}{ Faridkot } & Date of & 15 May & 96 & 2025 & 27941 & 188 & 3613 & 46335 & 0.51 \\
\hline & sowing & 1 June & 85 & 1760 & 23961 & 174 & 3241 & 41141 & 0.50 \\
\hline & & 15 June & 83 & 1678 & 22555 & 166 & 3000 & 37597 & 0.45 \\
\hline & Genotype & AL 15 & 76 & 1611 & 22048 & 175 & 3271 & 41561 & 0.46 \\
\hline & & AL 201 & 97 & 2007 & 27095 & 178 & 3307 & 41916 & 0.52 \\
\hline & & PAU 881 & 86 & 1807 & 24570 & 175 & 3280 & 41633 & 0.52 \\
\hline & & AL 1578 & 91 & 1885 & 25563 & 176 & 3282 & 41654 & 0.45 \\
\hline
\end{tabular}

Table 2. Effect of sowing dates and genotypes on plant height of pigeonpea at different locations.

\begin{tabular}{lccccc}
\hline \multirow{2}{*}{ Treatment } & \multicolumn{5}{c}{ Plant height $(\mathbf{c m})$} \\
\cline { 2 - 6 } & \multicolumn{5}{c}{ Location } \\
\cline { 2 - 6 } & Ludhiana & Gurdaspur & Bathinda & Faridkot & Mean \\
\hline Date of sowing & & & & - & 254.3 \\
1 May & 229.5 & 239.6 & 293.7 & 298.5 & 265.9 \\
15 May & 230.1 & 240.5 & 294.5 & 277.5 & 245.8 \\
1 June & 209.2 & 223.4 & 273.0 & 238.4 & 226.6 \\
15 June & 173.0 & 223.6 & 271.3 & & \\
CD (P=0.05) & 8.5 & 10.5 & 14.1 & 230.8 & 208.4 \\
\hline Genotype & & & 243.4 & 274.3 \\
AL 15 & 171.8 & 187.7 & 306.1 & 285.9 & 257.9 \\
AL 201 & 236.2 & 259.0 & 282.3 & 277.0 & 256.3 \\
PAU 881 & 232.5 & 234.5 & 300.6 & 8.9 & \\
AL 1578 & 201.4 & 246.0 & 11.1 & & \\
CD (P=0.05) & 7.5 & 13.6 & & & \\
\hline
\end{tabular}

duction with further delay in sowing from 1 June to 15 June. During the months of May and June, the maximum temperature and sunshine hours were higher as compared to July month (Fig. 1) and that is why the early sown crop acquired more heat units as compared to late sown crop.

Among dates of sowings, 15 May and 1 June sowings accumulated more heat units resulting in more heat use efficiencies than 15 June sowing. The highest heat use efficiency of $0.55 \mathrm{~kg} / \mathrm{ha} /{ }^{\circ} \mathrm{C}$ day at Ludhiana and 0.51 $\mathrm{kg} / \mathrm{ha} /{ }^{\circ} \mathrm{C}$ day at Faridkot was recorded when the crop was sown on 15 May (Table 1). While the lowest heat use efficiency of $0.35 \mathrm{~kg} / \mathrm{ha} /{ }^{\circ} \mathrm{C}$ day at Ludhiana and $0.45 \mathrm{~kg} / \mathrm{ha} /{ }^{\circ} \mathrm{C}$ day at Fraidkot was observed when the crop was sown on 15 June. A significant polynomial relationship was observed between grain yield and growing degree days (Fig. 2) for Ludhiana $\left(R^{2}=0.62\right)$ and Faridkot $\left(\mathrm{R}^{2}=0.51\right)$ while a significant linear function was observed between grain yield and heat use efficiency (Fig. 3) with $\mathrm{R}^{2}=0.96$ and $\mathrm{R}^{2}=0.83$ for Ludhiana and Faridkot, respectively.

The plant height was significantly $(\mathrm{p}=0.05)$ influenced by the date of sowing. The plant height at all the locations was highest under 15 May sowing which was, however at par with 1 May sowing. The plant height under May sowings (1 and 15 May) was more due to longer period of vegetative growth. A drastic reduction in plant height was recorded under delayed sowing compared to early date of sowing. It could be mainly attributed to the short growth period. Kumar et al. (2008) also reported reduced plant growth and yield attributes in case of delayed sowing in pigeonpea.

The pods/plant is an important yield attributing character. The crop sown on 15 May recorded significantly $(\mathrm{p}=0.05)$ higher number of pods/plant than other sowing dates at all the locations except Gurdaspur. The highest number of pods/plant in 15 May sown crop might be due to harmonic balance between vegetative and reproductive phase besides availability of sufficient time for pod setting. These findings are in agreement with those of Rani and Reddy (2010).The sowing dates did not affect the number of grains/pod at Ludhiana and Bathinda significantly (Table 3) whereas at Faridkot, it was significantly higher under 1 June sow- 
Guriqbal Singh et al. / J. Appl. \& Nat. Sci. 9 (4): 2377 - 2384 (2017)

Table 3. Effect of sowing dates and genotypes on the yield attributes of pigeonpea at different locations.

\begin{tabular}{|c|c|c|c|c|c|}
\hline \multirow{2}{*}{ Treatment } & \multicolumn{5}{|c|}{ Location } \\
\hline & Ludhiana & Gurdaspur & Bathinda & Faridkot & Mean \\
\hline Date of sowing & & & Pods/plant & & \\
\hline 1 May & 155.2 & 102.2 & 88.4 & - & 115.3 \\
\hline 15 May & 173.6 & 102.3 & 108.4 & 175.7 & 140.0 \\
\hline 1 June & 156.6 & 100.4 & 96.1 & 147.5 & 125.2 \\
\hline 15 June & 128.7 & 96.2 & 79.3 & 122.5 & 106.7 \\
\hline $\mathrm{CD}(\mathrm{P}=0.05)$ & 8.6 & NS & 10.8 & 10.9 & \\
\hline \multicolumn{6}{|l|}{ Genotype } \\
\hline AL 15 & 88.1 & 84.7 & 74.1 & 156.1 & 100.8 \\
\hline AL 201 & 198.3 & 107.1 & 106.1 & 161.7 & 143.3 \\
\hline PAU 881 & 171.9 & 98.5 & 96.7 & 155.5 & 130.7 \\
\hline AL 1578 & 155.8 & 110.7 & 95.3 & 121.0 & 120.7 \\
\hline $\mathrm{CD}(\mathrm{P}=0.05)$ & 12.1 & 10.63 & 8.9 & 8.6 & \\
\hline Date of sowing & & & Grains/poc & & \\
\hline 1 May & 4.19 & & 3.76 & - & 3.97 \\
\hline 15 May & 4.06 & & 3.73 & 3.71 & 3.83 \\
\hline 1 June & 4.09 & & 3.74 & 3.83 & 3.88 \\
\hline 15 June & 4.16 & & 3.78 & 3.46 & 3.78 \\
\hline $\mathrm{CD}(\mathrm{P}=0.05)$ & NS & & NS & 0.21 & \\
\hline \multicolumn{6}{|l|}{ Genotype } \\
\hline AL 15 & 4.16 & & 3.84 & 3.61 & 3.87 \\
\hline AL 201 & 4.15 & & 3.73 & 3.74 & 3.87 \\
\hline PAU 881 & 4.09 & & 3.66 & 3.32 & 3.69 \\
\hline AL 1578 & 4.10 & & 3.79 & 3.86 & 3.92 \\
\hline $\mathrm{CD}(\mathrm{P}=0.05)$ & NS & & NS & 0.17 & \\
\hline Date of sowing & \multicolumn{5}{|c|}{ 100-grain weight (g) } \\
\hline 1 May & 6.76 & 8.02 & 6.13 & - & 6.97 \\
\hline 15 May & 6.86 & 7.84 & 6.63 & 8.64 & 7.49 \\
\hline 1 June & 6.84 & 7.39 & 6.26 & 8.46 & 7.24 \\
\hline 15 June & 6.57 & 7.30 & 6.40 & 8.60 & 7.22 \\
\hline $\mathrm{CD}(\mathrm{P}=0.05)$ & 0.20 & 0.51 & 0.22 & $\mathrm{NS}$ & \\
\hline \multicolumn{6}{|l|}{ Genotype } \\
\hline AL 15 & 6.58 & 7.19 & 6.19 & 8.72 & 7.17 \\
\hline AL 201 & 7.20 & 7.89 & 6.57 & 8.27 & 7.48 \\
\hline PAU 881 & 6.49 & 7.58 & 6.52 & 8.36 & 7.24 \\
\hline AL 1578 & 6.76 & 7.90 & 6.15 & 8.92 & 7.43 \\
\hline $\mathrm{CD}(\mathrm{P}=0.05)$ & 0.17 & 0.37 & 0.20 & 0.19 & \\
\hline
\end{tabular}

ing than 15 June sowing. The 100-grain weight was the highest under May 15 sowing at all the locations except Gurdaspur.

The biological yield was significantly affected by date of sowing across all the tested agro-climatic locations (Table 4). Biological yields were highest at Bathinda and lowest at Ludhiana. The biological yield was significantly higher in 1 May sowing than the other sowing dates at Ludhiana and Bathinda. However, at Gurdaspur and Faridkot significantly higher values were observed under 15 May sowing than 1 June and 15 June sowing. Overall, biological yield was significantly reduced with delay in sowing due to shortening of growing season which in turn reduced the vegetative growth of the plant as reflected by the reduced plant height (Table 2).

At all the agro-climatic locations, the grain yield was significantly higher in 15 May sowing than other sowing dates (Table 4) due to more number of pods/plant, grains/pod and 100-grain weight. On the basis of means of all the locations, 15 May sowing gave 23.3,
22.1 and $46.7 \%$ higher grain yield over 1 May, 1 June and 15 June sowing, respectively. Our findings are in line with those of Ram et al. (2011) and Singh et al. (2016) who reported that 15 May sown pigeonpea crop produced significantly higher grain yield than 1 June and 15 June sown crop. The increased grain yield due to early sowing could be ascribed to the high leaf area index and its persistence, photosynthetically active radiation interception and absorption, leading to higher dry matter accumulation before the pigeonpea crop reached the reproductive stage (Patel et al. 2000). Other researchers also reported sharp decline in the grain yield of pigeonpea with delay in sowing time (Kumar et al. 2008; Singh et al. 2016). Contrarily, harvest index increased with delay in sowing (Table 4) primarily due to reduction in vegetative biomass. Owing to higher grain yield, crop sown on 15 May provided the highest gross as well as net returns and $\mathrm{B}: \mathrm{C}$ ratio at all the test locations (Table 5). On the basis of means of all the locations, 15 May sowing gave an additional income of Rs 13599, 13040 and 22865 per 
Guriqbal Singh et al. / J. Appl. \& Nat. Sci. 9 (4): 2377 - 2384 (2017)

Table 4. Effect of sowing dates and genotypes on the biological yield, grain yield and harvest index of pigeonpea.

\begin{tabular}{|c|c|c|c|c|c|}
\hline \multirow{2}{*}{ Treatment } & \multicolumn{5}{|c|}{ Location } \\
\hline & Ludhiana & Gurdaspur & Bathinda & Faridkot & Mean \\
\hline Date of sowing & \multicolumn{5}{|c|}{ Biological yield (kg/ha) } \\
\hline 1 May & 15679 & 17440 & 22979 & - & 18699 \\
\hline 15 May & 12688 & 18233 & 20750 & 16790 & 17115 \\
\hline 1 June & 7854 & 11703 & 17583 & 13200 & 12585 \\
\hline 15 June & 5000 & 11058 & 16917 & 9760 & 10683 \\
\hline $\mathrm{CD}(\mathrm{P}=0.05)$ & 840 & 3308 & 1211 & 1250 & \\
\hline \multicolumn{6}{|l|}{ Genotype } \\
\hline AL 15 & 7354 & 9558 & 18750 & 12410 & 12018 \\
\hline AL 201 & 11917 & 19318 & 19896 & 13660 & 16197 \\
\hline PAU 881 & 11471 & 13223 & 18833 & 13380 & 14226 \\
\hline AL 1578 & 10479 & 16335 & 20750 & 13550 & 15278 \\
\hline $\mathrm{CD}(\mathrm{P}=0.05)$ & 876 & 1768 & 1235 & NS & \\
\hline Date of sowing & \multicolumn{5}{|c|}{ Grain yield $(\mathrm{kg} / \mathrm{ha})$} \\
\hline 1 May & 1479 & 1283 & 1303 & - & 1355 \\
\hline 15 May & 1685 & 1360 & 1807 & 1833 & 1671 \\
\hline 1 June & 1335 & 1058 & 1457 & 1622 & 1368 \\
\hline 15 June & 931 & 1103 & 1159 & 1365 & 1139 \\
\hline $\mathrm{CD}(\mathrm{P}=0.05)$ & 75 & 70 & 92 & 201 & \\
\hline \multicolumn{6}{|l|}{ Genotype } \\
\hline AL 15 & 790 & 693 & 1240 & 1494 & 1054 \\
\hline AL 201 & 1806 & 1508 & 1380 & 1722 & 1604 \\
\hline PAU 881 & 1504 & 1155 & 1528 & 1733 & 1480 \\
\hline AL 1578 & 1331 & 1448 & 1577 & 1478 & 1458 \\
\hline $\mathrm{CD}(\mathrm{P}=0.05)$ & 91 & 92 & 108 & 154 & \\
\hline Date of sowing & \multicolumn{5}{|c|}{ Harvest index (\%) } \\
\hline 1 May & 9.4 & 7.3 & 5.6 & - & 7.4 \\
\hline 15 May & 13.9 & 7.5 & 8.7 & 10.9 & 10.3 \\
\hline 1 June & 19.3 & 9.0 & 8.3 & 12.3 & 12.2 \\
\hline 15 June & 19.0 & 10.0 & 6.9 & 14.0 & 12.5 \\
\hline \multicolumn{6}{|l|}{ Genotype } \\
\hline AL 15 & 10.7 & 7.3 & 6.6 & 12.0 & 9.2 \\
\hline AL 201 & 15.2 & 7.8 & 6.9 & 12.6 & 10.6 \\
\hline PAU 881 & 13.1 & 8.7 & 8.1 & 13.0 & 10.7 \\
\hline AL 1578 & 12.7 & 8.9 & 7.6 & 10.9 & 10.0 \\
\hline
\end{tabular}

ha over 1 May, 1 June and 15 June sowing, respectively.

Performance of genotypes: Among the genotypes, AL 201 showed edge over the other genotypes in terms of accumulated GDD and PTU and having highest HUE at Ludhiana and Faridkot (Table 1). The highest heat use efficiency in15 May sown crop might be due to higher production of grain yield per unit heat absorbed. Similar results were also reported by Tripathi et al. (2004). Any stress during anthesis and grainfilling is the major constraint of productivity so timely sown and thermo tolerant genotypes recorded higher grain yield by using accumulated heat units efficiently. The genotype AL 15 took least whereas AL 201 took highest days to $50 \%$ flowering and maturity both at Ludhiana and Faridkot.

The genotypes AL 201 and AL 15 attained the highest and lowest plant height, respectively at all the locations (Table 2). The number of pods/plant was recorded highest in AL 201 at all the locations except Gurdaspur where AL 1578 recorded highest value closely followed by AL 201 (Table 3). The grains/pod differed non-significantly at Ludhiana and Bathinda locations but at Faridkot, AL 1578 exhibited highest value. The genotype AL 201 recorded highest 100-grain weight at Ludhiana and Bathinda whereas at Gurdaspur and Faridkot it was highest in AL 1578.

The tested genotypes also differed significantly for biological yield at all the locations except for Faridkot location (Table 4). The biological yield of AL 201 was highest at Ludhiana and Gurdaspur whereas AL 1578 recorded highest biological yield at Bathinda. The grain yield also varied significantly as AL 201 performed best at Ludhiana and Gurdaspur while AL 1578 and PAU 881 resulted in highest yield at Bathinda and Faridkot locations, respectively. Several researchers have also reported genotypic variation with respect to growth and yield of pigeonpea (Mligo and Craufurd 2005; Egbe and Vange 2008; Singh et al. 2016). Differential response of different genotypes could be due to differences in growth, yield attributes, tolerance to insect pest and diseases etc. Similarly, harvest index was highest for genotype AL 201 at Ludhiana, AL 1578 at Gurdaspur and PAU 881 at Bathinda \& Farid- 
Table 5. Effect of sowing dates and genotypes on the monetary parameters of pigeonpea.

\begin{tabular}{|c|c|c|c|c|c|}
\hline \multirow{2}{*}{ Treatment } & \multicolumn{5}{|c|}{ Location } \\
\hline & Ludhiana & Gurdaspur & Bathinda & Faridkot & Mean \\
\hline Date of sowing & \multicolumn{5}{|c|}{ Gross returns (Rs/ha) } \\
\hline 1 May & 63597 & 55169 & 56029 & - & 58265 \\
\hline 15 May & 72455 & 58480 & 77701 & 78819 & 71864 \\
\hline 1 June & 57405 & 45494 & 62651 & 69746 & 58824 \\
\hline 15 June & 40033 & 47429 & 49837 & 58695 & 48999 \\
\hline \multicolumn{6}{|l|}{ Genotype } \\
\hline AL 15 & 33970 & 29799 & 53320 & 64242 & 39030 \\
\hline AL 201 & 77658 & 64844 & 59340 & 74046 & 68972 \\
\hline PAU 881 & 64672 & 49665 & 65704 & 74519 & 63640 \\
\hline AL 1578 & 57233 & 62264 & 67811 & 63554 & 62716 \\
\hline Date of sowing & \multicolumn{5}{|c|}{ Net returns (Rs/ha) } \\
\hline 1 May & 36027 & 27599 & 28459 & - & 30695 \\
\hline 15 May & 44885 & 30910 & 50131 & 51249 & 44294 \\
\hline 1 June & 29835 & 17924 & 35081 & 42176 & 31254 \\
\hline 15 June & 12463 & 19859 & 22267 & 31125 & 21429 \\
\hline \multicolumn{6}{|l|}{ Genotype } \\
\hline AL 15 & 6400 & 2229 & 25750 & 36672 & 11460 \\
\hline AL 201 & 50088 & 37274 & 31770 & 46476 & 41402 \\
\hline PAU 881 & 37102 & 22095 & 38134 & 46949 & 36070 \\
\hline AL 1578 & 29663 & 34694 & 40241 & 35984 & 35146 \\
\hline Date of sowing & \multicolumn{5}{|c|}{ B:C ratio } \\
\hline 1 May & 2.31 & 2.00 & 2.03 & - & 2.11 \\
\hline 15 May & 2.63 & 2.12 & 2.82 & 2.86 & 2.61 \\
\hline 1 June & 2.08 & 1.65 & 2.27 & 2.53 & 2.13 \\
\hline 15 June & 1.45 & 1.72 & 1.81 & 2.13 & 1.78 \\
\hline \multicolumn{6}{|l|}{ Genotype } \\
\hline AL 15 & 1.23 & 1.08 & 1.93 & 2.33 & 1.41 \\
\hline AL 201 & 2.82 & 2.35 & 2.15 & 2.69 & 2.50 \\
\hline PAU 881 & 2.35 & 1.80 & 2.38 & 2.70 & 2.31 \\
\hline AL 1578 & 2.08 & 2.26 & 2.46 & 2.31 & 2.28 \\
\hline
\end{tabular}

kot. Among monetary parameters, maximum gross returns, net returns and $\mathrm{B}: \mathrm{C}$ ratio primarily due to high grain yield were observed for AL 201 at Ludhiana and Gurdaspur, AL 1578 at Bathinda and PAU 881 at Faridkot location (Table 5).

\section{Conclusion}

Days to $50 \%$ flowering as well as maturity, growing degree days and photothermal units were reduced with delay in sowing of pigeonpea. The crop sown on 15 May recorded the highest plant height $(265.9 \mathrm{~cm})$, pods/plant (140.0), 100-grain weight (7.49 g), grain yield (1671 kg/ha), gross returns (Rs 71864 per ha) and net returns (Rs 44294 per ha). It can be concluded that 15 May is the optimum sowing date of pigeonpea and AL 201 and PAU 881 are the promising genotypes under diverse environments for providing high productivity of pigeonpea.

\section{ACKNOWLEDGEMENTS}

The authors are thankful to the Punjab Agricultural University, Ludhiana, India for providing facilities for conducting these trials.

\section{REFERENCES}

Bhavi, R., Desai, B.K. and Vinodakumar, S.N. (2013) Effect of planting geometry on the yield, nutrient availability and economics of pigeonpea genotypes. Trends in Biosciences 6: 773-775.

Cheema, H.S. and Singh, B.(1991) Software Statistical CPCS-1. Department of Statistics, Punjab Agricultural University, Ludhiana, India.

Egbe, M.O., Aku, A.A. and Odebiyi, S. (2013) Effect of planting dates on the performance of pigeonpea varieties in Southern Guinea Savanna ecology of Nigeria. Journal of Biology, Agriculture and Healthcare 8:2228.

Egbe, O.M. and Vange, T. (2008) Yield and agronomic characteristics of 30 pigeonpea genotypes at Otobi in Southern Guinea Savanna of Nigeria. Life Science Journal 5: $70-80$.

Esfandiary, F., Aghaie, G. and Mehr, A.D. (2009) Wheat yield prediction through agro meteorological indices for Ardebil District. International Journal of Biological Life Science 1:48-51.

FAOSTAT. (2017) http://www.fao.org/faostat/en/\#data/QC

Khichar, M.L. and Niwas, R. (2007) Thermal effect on growth and yield of wheat under different sowing environments and planting systems. Indian Journal of Agricultural Research 41: 92-96.

Kumar, N., Gopinath, K.A., Srivastva, A.K. and Mahajan, V. (2008) Performance of pigeonpea (Cajanus cajan L. Millsp.) at different sowing dates in the mid-hills of Indian Himalaya. Archives of Agronomy and Soil Sci- 
ence 54: 507-514.

Mligo, J.K. and Craufurd, P.Q. (2005) Adaptation and yield of pigeonpea in different environments in Tanzania. Field Crops Research 94: 43-53.

Nuttonson, M.Y. (1955) Wheat climatic relationship and use of phenology in ascertaining the thermal and photothermal requirements of wheat. American Institute of Crop Ecology Washington D.C.

Pandey, I.B., Pandey, R.K, Dwivedi, D.K. and Singh, R.S. (2010) Phenology, heat unit requirement and yield of wheat (Triticum aestivum) varieties under different crop -growing environment. Indian Journal of Agricultural Sciences 80: 136-140.

Patel, N.R., Mehta, A.N. and Shekh, A.M. (2000) Radiation absorption, growth and yield of pigeonpea cultivars as influenced by sowing dates. Experimental Agriculture 36: 291-301.

PAU (2011) Package of Practices for Crops of Punjab, Kharif 2011. Punjab Agricultural University, Ludhiana, India.

Prakash, V., Mishra J.S, Kumar, R., Kumar, R., Kumar, S., Dwivedi, S.K., Rao, K.K. and Bhatt, B.P. (2017) Thermal utilization and heat use efficiency of sorghum cultivars in middle Indo-Gangetic Plains. Journal of Agrometeorology 19: 29-33.

Prakash, V., Niwas R., Khichar, M.L., Sharma, D., Manmohan and Singh, B. (2015) Agrometeorological indices and intercepted photosynthetically active radiation in cotton crop under different environments. Journal of Cotton Research and Development 29: 268-272.
Ram, H., Singh, G., Sekhon, H.S. and Khanna, V. (2011) Effect of sowing time on the performance of pigeonpea genotypes. Journal of Food Legumes 24:207-210.

Rani, B.P. and Reddy, D.R. (2010) Performance of pigeonpea in sole and inter cropping system in vertisols of Krishna-Godavari zone in Andhra Pradesh. Indian Journal of Agricultural Research 44: 225-228.

Sekhon, H.S. and Singh, G. (2005) Influence of extra-short duration pigeonpea genotypes on pigeonpea-wheat cropping system. Indian Journal of Pulses Research 18: 3031.

Singh, G., Kaur, H., Aggarwal, N., Ram, H., Gill, K.K. and Khanna, V. (2016) Symbiotic characters, thermal requirement, growth, yield and economics of pigeonpea (Cajanus cajan) genotypes sown at different dates under Punjab conditions. Journal of Applied and Natural Science 8: 381-385.

Singh, S.S. and Singh, R. (2011) Crop management. pp. 182192. Kalyani Publishers, New Delhi.

Tripathi, P., Singh, A.K., Kumar, A. and Chaturvedi, A. (2004) Heat use efficiency of wheat (Triticum aestivum) genotypes under varying crop growing environment. Indian Journal of Agricultural Sciences, 74: 6-8.

Umesh, M.R., Shankar, M.A. and Ananda, N. (2013) Yield, nutrient uptake and economics of pigeonpea (Cajanus cajan L.) genotypes under nutrient supply levels in dryland Alfisols of Karnataka. Indian Journal of Agronomy 58: 554-559.

Wilson, C., Hui, D., Nwaneri, E., Wang, J., Deng, Q., Duseja, D. and Tegegne, F. (2012) Effects of planting dates, densities, and varieties on ecophysiology of pi- 